DOI: https://doi.org/10.47405/mjssh.v5i2.355

\begin{tabular}{|c|c|}
\hline $\mathrm{s}^{2}=$ & Malaysian Journal of Social Sciences and Humanities (MJSSH) \\
\hline Malaysian Journal of & Volume 5, Issue 2, February 2020 \\
\hline (MJ-SSH) & e-ISSN : 2504-8562 \\
\hline & $\begin{array}{l}\text { Journal home page: } \\
\text { www.msocialsciences.com }\end{array}$ \\
\hline
\end{tabular}

\title{
Leisure Activity Participation Pattern Among Klang Community
}

\author{
Nur Akif Najmi Bin Zurkifli', Rozita Binti Abdul Latif ${ }^{1}$ \\ 1Fakulti Sains Sukan dan Rekreasi, Universiti Teknologi MARA (UiTM) \\ Correspondence: Nur Akif Najmi Bin Zurkifli (nurakifnajmi08@gmail.com)
}

\begin{abstract}
The main purpose of this study was to identify the pattern of participation of Klang community towards leisure time activity. This study involved 421 total respondents in Klang. The methodology used was quantitative method and the instrument of the questionnaire was adapted and adopted from Godin and Shephard, (1997). Besides, the results also showed facility near a community that may be used by them and the questionnaire was adapted and adopted from Sylvia, (2004). The results showed a different group of people run different patterns of activity as these activities counted daily in a week. Overall Klang community had chosen activities in house as their most done activities such as surfing the internet and cooking. Besides, the different groups of gender used to run different sports activities same goes to a different group of ages as badminton and futsal were most sports activities done by the community. In conclusion, a different group of gender and ages run different patterns of activities in Klang.
\end{abstract}

Keywords: pattern of participation, activities done in a week, Klang community

\section{Introduction}

Leisure is defined as a freely chosen activity, which involves meaningful, internally motivated, and enjoyable experiences outside of obligatory works, such as school or a job (Godbey, 1994; Rahim, et.al, 2011). Some form of physical exertion during free time, such as sports and physical activity are referred to as active leisure, whereas passive leisure is characterized as a restful, static and quiet timeout activity in which one does not engage in physical exertion during free time (Joudrey \& Wallace, 2009). Leisure is defined as a freely chosen activity, which involves meaningful, internally motivated, and enjoyable experiences outside of obligatory works, such as school or a job (Godbey, 1994). According to Kim (2018), leisure can be classified into two which are active leisure and passive leisure.

Leisure-time physical activity is associated with reduced risks for mortality from all causes, cardiovascular disease (CVD), and cancer (Donnovan, 2017). Regular physical activity plays a major role in maintaining good physical and mental health and in the prevention of non-communicable diseases (Josephine, 2017). According to Badura, (2015), Participation in organized leisure-time activities (OLTA) has been linked to healthy youth development.

Participation in informal and formal leisure activities supports children in developing functional social skills and helps them to form social networks and friendships. It provides opportunities to learn and 
develop skills, can provide children with a sense of belonging, and promotes long-term mental and physical health (Anna, 2013).

Leisure-time physical activity (LTPA) considered one of the most important physical activity domains for public health intervention and research. It is an important subtype of physical activity (PA) for research and behavior change intervention in the oncology context. Compared to household, occupational, and commuting physical activities, leisure-time physical activity may provide the greatest opportunity for enjoyment and improvement in fitness- and health-related benefits (Amireault, 2015). Leisure can happen inside organized or unorganized environments. An individual can gain from leisure in a formal or informal manner. The idea of leisure is frequently identified with the opportunity for people to be what they want and the opportunity from limitations that keep people from looking for fulfilling closes (Edginton, 2006). Leisure regularly includes people looking for joy and satisfaction living. There might be sure suddenness to the leisure experience wherein the pioneer of action tries to make a structure without denying people of their apparent opportunity (Edginton, 2006).

The mixing and advancement of physical activity in leisure conditions may hold an incredible guarantee of improving the lives of people. For most children and youth, leisure time gives a phenomenal scene to physical exercises going from informal play to increasingly intricate and profoundly sorted out sports and athletic occasions (Edginton, 2006). For adults, most, if not all, physical action will happen during their leisure time. With legitimate instructive and coaching projects, children and youth can convey into their adulthood the qualities and advantages picked up from taking an interest in leisure-time physical activity (Edginton, 2006).

In global, there were different patterns of leisure-time physical activity participation among children, adolescents and adults. The participation of child and adolescent were highly dependent upon the region. Besides, the participation of youth team sport in American was high meanwhile the likely participation in lifelong physical activities was high in the Eastern Mediterranean and Western Pacific. Next, running and walking were consistent participation for adults globally. Among all these age groups and regions, soccer most popular among them (Hulteen, 2016).

The participation of leisure activity can be defined as how humans contribute their free time towards an activity that is free from rules and regulations. It is shown that participation in leisure activity been done in free time. Leisure activity also can be defined as people utilized their time to perform various activities (Torkildsen, 2005). While, leisure patterns, like other aspects of human behavior, are believed to exhibit both change and continuity across the life span (Iso-Ahola, 1980; Kelly, 1974, 1977). According to Iso-Aloha (1980), as individuals age, they are changing physical, psychological, and social circumstances impact on the ways they use their free time.

Hulteen (2007), founded that there were activities that been done by most of the group of age globally which were children, adolescents, and adults. These activities were categorized as lifelong physical activity and team sports activity.

Table 1: Top five activities been participate globally

\begin{tabular}{ccc}
\hline Group of age & Activities & Purpose \\
\hline \multirow{2}{*}{ Children } & Soccer & Team sport \\
& Basketball & Team sport \\
& Volleyball & Team sport \\
& Baseball & Team sport \\
& Swimming & Lifelong physical activity \\
Adolescent & Swimming & Lifelong physical activity \\
& Running & Lifelong physical activity \\
& Soccer & Team sport \\
& Cycling & Lifelong physical activity
\end{tabular}


Malaysian Journal of Social Sciences and Humanities (MJSSH), Volume 5, Issue 2, (page 21 - 35), 2020 DOI: https://doi.org/10.47405/mjssh.v5i2.355

$\begin{array}{ccl} & \text { Walking } & \text { Lifelong physical activity } \\ \text { Adult } & \text { Running } & \text { Lifelong physical activity } \\ \text { Walking } & \text { Lifelong physical activity } \\ \text { Cycling } & \text { Lifelong physical activity } \\ \text { Swimming } & \text { Lifelong physical activity } \\ & \text { Resistance training } & \text { Lifelong physical activity }\end{array}$

Gender orientation is the most grounded contributing variable to contrasts in relaxation designs, even among the informed. Men general take part in dynamic recreation, while ladies take part in aloof relaxation because of natural contrasts as well as conventional gender orientation jobs in which ladies are bound to get associated with parental figure's jobs inside the home, which may decrease the nature of relaxation for ladies (Andrijašević et al., 2005; Bittman \& Wajcman, 2000; McGinnis, Chun, \&McQuillan, 2003).

In addition, male university students interest in games and physical movement more than female college students, while the females seek after progressively detached relaxation, for example, tuning in to music, perusing books and magazines, going to chapel, taking part in family and family tasks, and taking treks (Andrijašević et al., 2005; Bouillet, Ilisin, \& Potocnik, 2008; Rahim et al., 2011). Because of thought processes in partaking in recreation exercises contrast among young men and young women (Leversen et al., 2012). Young ladies are all the more socially roused (Francis \&Kentel, 2008) and see 'accomplishment recreation' as characterized (Passmore \& French, 2001) to be less charming than young fellows do. Young ladies appear to be more pulled in to organized exercises and young men to unstructured exercises (Geidne et al., 2015; Lindström and Öqvist, 2013).

Also, male understudies contribute about twice as much vitality looking into physical activities as female students do and they partake in recreation clubs multiple times more than female understudies do. This is unsurprising with the investigation in which female students were shown to be slanted to pick isolates unwinding practices just as to require in clear amusement capacities when appeared differently in relation to male understudies (Hickerson and Beggs, 2007). In addition, females are almost certain than males to create wellbeing distress related to an absence of physical action (Andrijašević et al., 2005; Buckworth, 2001).

\section{Public facilities}

The network of public facilities represents one of the many factors that influence the quality of life within the urban environment (Ana, 2016). One of the main attributes of the public facilities is that they provide members of the local community with the services they require in order to live a qualitative life, such as unlimited access to elementary, secondary and tertiary education, health facilities (for both preventing and dealing with health problems), commercial facilities, green areas, public parking, etc. (Ana, 2016).

In addition, the network of public facilities positively influences the society by providing work for a large number of citizens, from different backgrounds and with various specializations that can thus reach their potential, while also contributing to the well-being of the community as a whole. But the most important attribute of the public facilities is that they dramatically increase the attraction potential of the public space, thus playing a crucial role within the urban network (Ana, 2016). In other words, the public facilities animate the built tissue, attracting people and generating activities, an essential factor for a lively urban environment, as well as for a qualitative urban life (Ana, 2016).

Based on a previous study in Norway, sports facilities have formed part of Norwegian public health policies to increase physical activity among children and adolescents. According to Torgeir (2008), the results had explored 662 young people's who were (age6-9 years), used 19 different kinds of sports facilities. According to Torgeir (2008), the findings indicate that sports facilities, in general, were less 
DOI: https://doi.org/10.47405/mjssh.v5i2.355

used by girls, adolescents (14-16 years) and the least active (physically active $\leq 1$ times/week outside school) than by boys, children (6-13 years) and the most active (physically active $\geq 4$ times/ week outside school). More general, multifunctional facilities were used to a greater extent than specialized facilities, particularly by the least active. Distance to the facility was important for the use of common facilities (Torgeir, 2008).

The purpose of this study is to investigate the leisure activity participation pattern among Klang community and identify public facilities that can be used by Klang community.

\section{Methodology}

The researcher used a quantitative method under the descriptive research to collect data to identify the most activity been done by Klang district community in a week. Besides, the use of descriptive research is to identify public facilities in near Klang community. So, the use of descriptive research would count the frequency of both objectives.

\section{Respondent}

The population of Klang district's community, Selangor in 2010 was around 861,189 (www.citypopulation.de), so that the sample size was $(\mathrm{N}=383)$. The probability sampling that was used by the researcher was convenience sampling which the researcher choose random Klang community to answer the questionnaires. 421 respondents had involved in this study. For gender, there were $234(55.6 \%)$ male respondents and 187(44.4\%) female. Besides, respondents involved in this study were within the age group from 19 to 65 years old and others, which is below 19 and above 65 years old. The percentages of 19 years old and below was 69(16.4\%), $20-34$ years old was $241(57.2 \%), 35$ - 49 years old was 78(18.5), 50 - 64 years old was $24(5.7 \%)$ and 65 years old and above was $9(2.1 \%)$. Other than that, it showed the sector of occupation of respondents which were government $98(23.3 \%)$, private $133(31.6 \%)$, self-employed14(3.3\%) and unemployed 176(41.8\%). Lastly, the result shows monthly income of respondents which were no income $(41.8 \%)$, less than RM1,500 (12.6\%), RM1,500-RM2,499 (19.2\%), RM2,500-RM3,499 (14.5\%) and more than RM3,500 (11.9\%).

\section{Instrumentation}

The questionnaire was an instrument of the research that consists of a set of questions to obtain information from the respondents. The questionnaire is provided in two languages which covered both Malay and English language. There were three sections that will be cover by the proposed questionnaire which were section A consist of demographic profile- it consists of six questions started with gender, age, marital status, race, occupation, and monthly income.

Section B consist of activity done in a week consists of sports, active recreation, passive recreation, academic activities and activities at home adapted and adopted from Godin and Shephard (1997) and section C of this questionnaire on public facility near home and how "easy' to use it by Sylvia (2004) consist of 11 elements. The studies were used Likert-4 scale, with "too difficult" (1 point) to "too easy" (4).

\section{Data Collection Procedure}

The researcher was seeking approval of ethics first before the actual research conducted. The questionnaire distributed to the respondent after the supervisor had approved the questionnaire. The researcher collected the questionnaire after the respondent completed answering the questionnaire. In this research, the researcher was analyzed by using the Statistical Package for Social Science (SPSS) Version 21, which transforms raw data into a value from that will provide a variety of information to identify all the factors in a situation. 


\section{Findings}

There were a total of 421 respondents answered the questionnaire completely and no missing data based on the data collection. For gender, there were 234 males respondents and 187 females. Besides, respondents involved in this study were within the age group from 19 to 65 years old and others which is below 19 and above 65 years old. The percentages shown in the table were 19 years old and below was $69,20-34$ years old was $241,35-49$ years old was $78,50-64$ years old was 24 and 65 years old and above was 9 . Then, the results of the research were stated below.

\section{Leisure activities been done by Klang community in a week}

Table 2.0 showed most activity been done by an overall of the respondents during their free time in a week. These activities were included, sports activities, active recreation, and passive recreation activities. The table shows the most activity done on Monday were surfing the internet (113), watching television (75), futsal (61), cooking (33) and jogging (21). The most activities have been done on Tuesday were surfing the internet (121), cooking (74), watching television (71), badminton (32) and playing a video game (28). Next, most activity been done on Wednesday were cooking (113), surfing the internet (90), badminton (60) watching television (58) and jogging (50). Most activities done on Thursday by Klang district community were surfing the internet (96), cooking (61), badminton (33), gymnasium (23) and futsal (20). Besides, most activities done on Friday were surfing the internet (105), cooking (56) watching television (48), hang out with friends (29) and playing a video game (29). On Saturday, the most activity done was jogging (75), cooking (68) cinema (56), badminton (30) and shopping (19). Lastly, most activities done on Sunday were jogging (105), cinema (84) surfing internet (53), cooking (48) and hang out with family (33).

Table 2: Most activity done by overall Klang community

\begin{tabular}{|c|c|c|}
\hline \multirow[t]{2}{*}{ Day } & \multicolumn{2}{|c|}{ Overall } \\
\hline & Activity & Frequency (n) \\
\hline \multirow[t]{5}{*}{ Monday } & Surfing internet & 113 \\
\hline & Watching television & 75 \\
\hline & Futsal & 61 \\
\hline & Cooking & 33 \\
\hline & Jogging & 21 \\
\hline \multirow[t]{5}{*}{ Tuesday } & Surfing internet & 121 \\
\hline & Cooking & 74 \\
\hline & Watching television & 71 \\
\hline & Badminton & 32 \\
\hline & Playing video game & 28 \\
\hline \multirow[t]{5}{*}{ Wednesday } & Cooking & 113 \\
\hline & Surfing internet & 90 \\
\hline & Badminton & 60 \\
\hline & Watching television & 58 \\
\hline & Jogging & 50 \\
\hline \multirow[t]{5}{*}{ Thursday } & Surfing internet & 96 \\
\hline & Cooking & 61 \\
\hline & Badminton & 33 \\
\hline & Gymnasium & 23 \\
\hline & Futsal & 20 \\
\hline \multirow[t]{2}{*}{ Friday } & Surfing internet & 105 \\
\hline & Cooking & 56 \\
\hline
\end{tabular}


DOI: https://doi.org/10.47405/mjssh.v5i2.355

Watching television 48

Hangout with friends 29

Playing video game 29

Saturday

Jogging 75

Cooking 68

Cinema 56

Badminton 30

Shopping 19

Sunday Jogging 105

Cinema 84

Surfing internet 53

Cooking 48

Hangout with family 33

Table 3: Most activity done in a week by gender

\begin{tabular}{ccc}
\hline Gender & Activity & Frequency $(\mathrm{n})$ \\
\hline Male & Surfing internet & 271 \\
& Futsal & 99 \\
& Badminton & 97 \\
& Jogging & 93 \\
& Playing video game & 85 \\
& & \\
Female & Surfing internet & 287 \\
& Cooking & 271 \\
& Jogging & 181 \\
& Watching television & 164 \\
& Sleeping & 25 \\
& & \\
\hline
\end{tabular}

The table above shows most activities that been done by gender. These activities counted based on the total participation by the groups of gender. The most activity that been done by male were surfing internet $(n=271)$, futsal $(n=99)$, badminton $(n=97)$, jogging $(n=93)$ and playing video game $(n=85)$. Besides, a most activity that been done by females was surfing the internet $(n=287)$, cooking $(n=271)$, jogging $(\mathrm{n}=181)$, watching television $(\mathrm{n}=164)$ and sleeping $(\mathrm{n}=25)$.

Table 4: Most activity done by group of age

\begin{tabular}{ccc}
\hline Group of age & Activity & Frequency (n) \\
\hline Adolescent & Cinema & 48 \\
& Jogging & 47 \\
& Badminton & 47 \\
& Basketball & 27 \\
& Watching television & 24 \\
Early adult & Surfing internet & 355 \\
& Jogging & 144 \\
& Cooking & 125 \\
& Watching television & 117 \\
& Badminton & 94 \\
Middle-aged adult & & 105
\end{tabular}


DOI: https://doi.org/10.47405/mjssh.v5i2.355

$\begin{array}{ccc} & \text { Badminton } & 98 \\ & \text { Jogging } & 94 \\ & \text { Hangout with family } & 37 \\ \text { Late adult } & \text { Cinema } & 32 \\ & \text { Cooking } & 113 \\ & \text { Watching television } & 95 \\ & \text { Walking at park } & 69 \\ \text { Surfing internet } & 40 \\ & \text { Jogging } & 15\end{array}$

The table above shows most activities that been done by a group of ages. These activities counted based on the total participation by these groups of age. The most activity that been done by adolescents has watched a movie in the cinema $(n=48)$, jogging $(n=47)$, badminton $(n=47)$, basketball $(n=27)$ and watching television $(\mathrm{n}=24)$. Besides, the most activity that been done by an early adult was surfing the internet $(n=355)$, jogging $(n=144)$, cooking $(n=125)$, watching television $(n=117)$ and badminton $(\mathrm{n}=94)$. The most activity that been done by a middle-aged adult were cooking $(\mathrm{n}=105)$, badminton $(n=98)$, jogging $(n=94)$, hang out with family $(n=37)$ and cinema $(n=32)$. Besides, the most activity that been done by a late adult was cooking $(n=113)$, watching television $(n=95)$, walking at the park $(n=69)$, surfing the internet $(n=40)$ and jogging $(n=15)$.

Table 5: Top five activities done by gender

\begin{tabular}{|c|c|c|c|c|}
\hline \multirow[t]{2}{*}{ Day } & \multicolumn{2}{|l|}{ Male } & \multicolumn{2}{|c|}{ Female } \\
\hline & Activity & $\begin{array}{c}\text { Frequency } \\
\text { (n) }\end{array}$ & Activity & Frequency (n) \\
\hline \multirow{5}{*}{ Monday } & Surfing internet & 56 & Surfing internet & 64 \\
\hline & Futsal & 55 & Cooking & 61 \\
\hline & Watching television & 30 & Watching television & 35 \\
\hline & Badminton & 23 & Jogging & 19 \\
\hline & Hangout with friends & 15 & Netball & 10 \\
\hline \multirow[t]{5}{*}{ Tuesday } & Surfing internet & 41 & Surfing internet & 83 \\
\hline & Hangout with friend & 24 & Watching television & 47 \\
\hline & Playing video game & 24 & Cooking & 45 \\
\hline & Jogging & 18 & Badminton & 25 \\
\hline & Cooking & 18 & Sleeping & 12 \\
\hline \multirow[t]{5}{*}{ Wednesday } & Badminton & 51 & Surfing internet & 59 \\
\hline & Surfing internet & 38 & Cooking & 35 \\
\hline & Jogging & 19 & Watching television & 30 \\
\hline & Playing video game & 19 & Badminton & 20 \\
\hline & Futsal & 14 & Jogging & 17 \\
\hline \multirow[t]{5}{*}{ Thursday } & Futsal & 30 & Cooking & 46 \\
\hline & Surfing internet & 28 & Surfing internet & 40 \\
\hline & Badminton & 23 & Badminton & 30 \\
\hline & Gymnasium & 21 & Watching television & 15 \\
\hline & Playing video game & 14 & Sleeping & 13 \\
\hline \multirow[t]{4}{*}{ Friday } & Surfing internet & 64 & Surfing internet & 41 \\
\hline & Hangout with friend & 29 & Cooking & 24 \\
\hline & Playing video game & 28 & Watching television & 24 \\
\hline & Jogging & 13 & Jogging & 19 \\
\hline
\end{tabular}


DOI: https://doi.org/10.47405/mjssh.v5i2.355

Fishing $\quad 13 \quad$ Futsal

10

Continue...

...continued

$\begin{array}{lcccr}\text { Saturday } & \text { Cinema } & 37 & \text { Jogging } & 56 \\ & \text { Football } & 27 & \text { Cooking } & 34 \\ \text { Jogging } & 19 & \text { Aerobic } & 16 \\ & \text { Watching television } & 15 & \text { Athletic } & 10 \\ \text { Shopping } & 14 & \text { Futsal } & 10 \\ \text { Sunday } & & & 66 \\ & \text { Surfing internet } & 44 & \text { Cinema } & 53 \\ & \text { Jogging } & 43 & \text { Jogging } & 30 \\ & \text { Hangout with family } & 19 & \text { Watching television } & 26 \\ \text { Gardening } & 15 & \text { Cooking } & 15\end{array}$

The table above shows the highest activity that been done every day in a week. The most activity that been done by the male on Monday was surfing the internet $(n=56)$, futsal $(n=55)$, watching television $(n=30)$, badminton $(n=23)$ and hang out with friends $(n=15)$. Besides, most activities that been done on Tuesday were surfing the internet $(n=41)$, hang out with friends $(n=24)$, playing a video game $(n=24)$, jogging $(n=18)$ and cooking $(n=18)$. Next, the most activity that have been done in Wednesday were badminton $(n=51)$, surfing internet $(n=38)$, jogging $(n=19)$, playing video game $(n=19)$ and futsal $(n=14)$. Other than that, activities that been done the most on Thursday were futsal $(n=30)$, surfing the internet $(n=38)$, badminton $(n=23)$, gymnasium $(n=21)$ and playing a video game $(n=14)$. Furthermore, most activities that been done on Friday were surfing the internet $(n=64)$, hang out with friends $(n=29)$, playing a video game $(\mathrm{n}=28)$, jogging $(\mathrm{n}=13)$ and fishing $(\mathrm{n}=13)$. In addition, the most activity that been done in Saturday were cinema $(n=37)$, football $(n=27)$, jogging $(n=19)$, watching television $(n=15)$ and shopping $(n=14)$. Finally, yet importantly, most activities that been done on Sunday were surfing the internet $(n=44)$, jogging $(n=43)$, hang out with family $(n=19)$, gardening $(n=15)$ and cooking $(\mathrm{n}=15)$.

While the most activity that been done by female in Monday were surfing internet ( $\mathrm{n}=64)$, cooking $(\mathrm{n}=61)$, watching television $(\mathrm{n}=35)$, jogging $(\mathrm{n}=19)$ and netball $(\mathrm{n}=10)$. Besides, most activities that been done in Tuesday were surfing internet $(n=83)$, watching television $(n=47)$, cooking $(n=24)$, badminton $(\mathrm{n}=25)$ and sleeping $(\mathrm{n}=12)$. Next, the most activity that have been done in Wednesday were surfing internet $(n=59)$, cooking $(n=35)$, watching television $(n=30)$, badminton $(n=20)$ and jogging $(n=17)$. Other than that, activities that been done the most in Thursday were cooking $(n=46)$, surfing internet $(n=40)$, badminton $(n=30)$, watching television $(n=15)$ and sleeping $(n=13)$.Furthermore, most activities that been done in Friday were surfing internet $(n=41)$, cooking $(n=24)$, watching television $(n=24)$, jogging $(n=19)$ and futsal $(n=10)$. In addition, the most activity that been done in Saturday were jogging $(n=56)$, cooking $(n=34)$, aerobic $(n=16)$, athletic $(n=10)$ and futsal $(n=10)$. Lastly, most activities that been done in Sunday were cinema $(n=66)$, jogging $(n=53)$, watching television $(n=30)$, cooking $(n=26)$ and house cleaning $(n=15)$.

Table 6: Top five activities done by adolescent

\begin{tabular}{ccc}
\hline Day & \multicolumn{3}{c}{ Adolescent } \\
\hline Activity & Frequency (n) \\
\hline \multirow{2}{*}{ Monday } & Futsal & 10 \\
& Netball & 10 \\
& Basketball & 9
\end{tabular}


Malaysian Journal of Social Sciences and Humanities (MJSSH), Volume 5, Issue 2, (page 21 - 35), 2020

DOI: https://doi.org/10.47405/mjssh.v5i2.355

$\begin{array}{ll}\text { Football } & 5 \\ \text { Dance } & 5\end{array}$

Tuesday

Wednesday

Thursday

Saturday

Sunday

$\begin{array}{cc}\text { Watching television } & 14 \\ \text { Takraw } & 10 \\ \text { Badminton } & 9 \\ \text { Basketball } & 9 \\ \text { Playing video game } & 9\end{array}$

Badminton $\quad 10$

Football 10

Netball 5

Hockey 5

Dance 5

Hockey 10

Badminton 9

Dance 5

Football 5

Playing video game 5

$\begin{array}{lll}\text { Friday } & \text { Basketball }\end{array}$

Football 5

Volleyball 5

Hockey 5

Dance 5

Cinema 29

Jogging 19

Football 10

Badminton 9

House cleaning 5

Jogging 28

Cinema 19

Futsal 10

Surfing internet 10

Watching television $\quad 10$

The table above shows the highest activity that been done every day in a week. The result showed the top five activities that been done by the adolescent. The most activity that been done in Monday were futsal $(n=10)$, netball $(n=10)$, basketball $(n=9)$, football $(n=5)$ and dance $(n=5)$. Besides, most activities that been done on Tuesday were watching television $(n=14)$, takraw $(n=10)$, badminton $(n=9)$, basketball $(n=9)$ and playing a video game $(n=9)$. Next, the most activity that has been done on Wednesday were badminton $(n=10)$, football $(n=10)$, netball $(n=5)$, hockey $(n=5)$ and dance $(n=5)$. Other than that, activities that been done the most on Thursday were hockey $(n=10)$, badminton $(n=9)$, dance $(n=5)$, football $(n=5)$ and playing a video game $(n=5)$.

Furthermore, most activities that been done in Friday were basketball $(n=9)$, football $(n=5)$, volleyball $(\mathrm{n}=5)$, hockey $(\mathrm{n}=5)$ and dance $(\mathrm{n}=5)$. In addition, the most activity that been done in Saturday were cinema $(n=29)$, jogging $(n=19)$, football $(n=10)$, badminton $(n=9)$ and house cleaning $(n=5)$. Lastly, most activities that been done in Sunday were jogging $(n=28)$, cinema $(n=19)$, futsal $(n=10)$, surfing internet $(\mathrm{n}=10)$ and watching television $(\mathrm{n}=10)$. 
Table 7: Top five activities done by adult

\begin{tabular}{|c|c|c|}
\hline \multirow[t]{2}{*}{ Day } & \multicolumn{2}{|c|}{ Early Adult } \\
\hline & Activity & Frequency (n) \\
\hline \multirow[t]{5}{*}{ Monday } & Surfing internet & 56 \\
\hline & Futsal & 53 \\
\hline & Watching television & 51 \\
\hline & Jogging & 35 \\
\hline & Badminton & 20 \\
\hline \multirow[t]{5}{*}{ Tuesday } & Surfing internet & 73 \\
\hline & Watching television & 42 \\
\hline & Hangout with friends & 29 \\
\hline & Jogging & 23 \\
\hline & Badminton & 19 \\
\hline \multirow[t]{5}{*}{ Wednesday } & Surfing internet & 79 \\
\hline & Playing video game & 38 \\
\hline & Sleeping & 27 \\
\hline & Cooking & 26 \\
\hline & Watching television & 24 \\
\hline \multirow[t]{5}{*}{ Thursday } & Badminton & 40 \\
\hline & Gymnasium & 30 \\
\hline & Futsal & 25 \\
\hline & Jogging & 24 \\
\hline & Cooking & 24 \\
\hline \multirow[t]{6}{*}{ Friday } & Surfing internet & 63 \\
\hline & Cooking & 38 \\
\hline & Jogging & 29 \\
\hline & Futsal & 15 \\
\hline & House cleaning & 15 \\
\hline & & Continue.... \\
\hline \multicolumn{3}{|l|}{....continued } \\
\hline \multirow[t]{5}{*}{ Saturday } & Cooking & 37 \\
\hline & Jogging & 33 \\
\hline & Surfing internet & 22 \\
\hline & House cleaning & 19 \\
\hline & Badminton & 15 \\
\hline \multirow[t]{5}{*}{ Sunday } & Cinema & 38 \\
\hline & Shopping & 37 \\
\hline & Surfing internet & 33 \\
\hline & Hangout with family & 29 \\
\hline & Playing video game & 18 \\
\hline
\end{tabular}

The table above shows the highest activity that been done every day in a week. The result showed the top five activities that been done by an early adult. The most activity that been done in Monday were surfing internet $(n=56)$, futsal $(n=53)$, watching television $(n=51)$, jogging $(n=35)$ and badminton $(\mathrm{n}=20)$. Besides, most activities that been done on Tuesday were surfing the internet $(\mathrm{n}=73)$, watching television $(n=42)$, hang out with friends $(n=29)$, jogging $(n=23)$ and badminton $(n=19)$. Next, the most activity that has been done on Wednesday was surfing the internet $(\mathrm{n}=79)$, playing a video game $(n=38)$, sleeping $(n=27)$, cooking $(n=26)$ and watching television $(n=24)$. Other than that, activities that 
been done the most on Thursday were badminton $(n=40)$, gymnasium $(n=30)$, futsal $(n=25)$, jogging $(n=24)$ and cooking $(n=24)$.

Furthermore, most activities that been done in Friday were surfing internet $(n=63)$, cooking $(n=38)$, jogging $(n=29)$, futsal $(n=15)$ and house cleaning $(n=15)$. In addition, the most activity that been done in Saturday were cooking $(n=37)$, jogging $(n=33)$, surfing internet $(n=22)$, house cleaning $(n=19)$ and badminton $(\mathrm{n}=15)$. Last but not least, most activities that been done in Sunday were cinema $(\mathrm{n}=38)$, shopping $(n=37)$, surfing internet $(n=33)$, hangout with family $(n=29)$ and playing video game $(n=18)$.

\section{Public facilities in Klang community residents}

Based on table 8.0, the most public facilities that existed around was a recreational park (217), followed by football field (213), badminton court (204), jogging track (192) running track (148), and sports complex (143). Next, the medium facilities existed around was takraw court (129), followed by basketball court (116), swimming pool (115), and tennis court (75) while the least existence of public facilities around was volleyball court (72).

Table 8: Existence of public facilities

\begin{tabular}{lcc}
\hline Types of Public Facilities & Male \\
\hline & Yes (n) & No (n) \\
\hline Football field & 213 & 21 \\
Takraw court & 129 & 105 \\
Basketball court & 116 & 118 \\
Tennis court & 75 & 159 \\
Volleyball court & 72 & 162 \\
Badminton court & 204 & 30 \\
Swimming pool & 115 & 119 \\
Running track & 148 & 86 \\
Sport complex & 143 & 91 \\
Jogging track & 192 & 42 \\
Recreational park & 217 & 17 \\
& &
\end{tabular}

Table 9: Public facilities access

\begin{tabular}{lcccccccc}
\hline Types of public facility & \multicolumn{1}{c}{ Access to public facility } \\
\hline & \multicolumn{1}{c}{ Too difficult } & \multicolumn{2}{c}{ Difficult } & \multicolumn{3}{c}{ Easy } & \multicolumn{3}{c}{ Too easy } \\
\hline & $\mathrm{M}$ & $\mathrm{F}$ & $\mathrm{M}$ & $\mathrm{F}$ & $\mathrm{M}$ & $\mathrm{F}$ & $\mathrm{M}$ & $\mathrm{F}$ \\
\cline { 2 - 9 } Football field & 17 & 36 & 37 & 42 & 53 & 51 & 127 & 58 \\
Takraw court & 78 & 104 & 50 & 32 & 33 & 23 & 73 & 28 \\
Basketball court & 76 & 61 & 66 & 55 & 28 & 25 & 64 & 46 \\
Tennis court & 117 & 72 & 61 & 41 & 38 & 49 & 18 & 25 \\
Volleyball court & 115 & 78 & 59 & 76 & 24 & 5 & 36 & 28 \\
Badminton court & 25 & 23 & 2 & 32 & 67 & 19 & 137 & 113 \\
Swimming pool & 72 & 76 & 57 & 33 & 54 & 46 & 51 & 32 \\
Running track & 53 & 65 & 46 & 48 & 53 & 34 & 82 & 40 \\
Sport complex & 68 & 47 & 50 & 54 & 14 & 51 & 102 & 35 \\
Jogging track & 36 & 32 & 32 & 33 & 76 & 48 & 90 & 74 \\
Recreational park & 4 & 18 & 18 & 10 & 29 & 22 & 183 & 137 \\
& & & & & & & & \\
\hline
\end{tabular}

The table above shows the too easy facility to been access by the male was recreational park (183). Besides, easy access to the public facility is the jogging track (76). The difficult access is basketball court (66) and the too difficult to access was tennis court (117). While females assume recreational 
park amenities were too easy facility to access (137). Besides, the easy access to the public facility was the football field and sports complex (51). The difficult access is volleyball court (76) and the too difficult to access was takraw court (104).

\section{Discussion}

Klang district community has done many types of activity in a week. The sedentary activities such as working, going to school, tuition, music class did dominate the most activities of Klang community but all of these activities did not count as leisure activity because the Klang community did all of those activities to fulfill their necessary activity to improve their knowledge and gaining income and not did that in leisure time.

The activities that participate the most by gender divided into two. There are 234 male respondents out of 421 respondents. From this result, the researcher identified that the male community of Klang had done the highest sports activities which were futsal $(n=99)$ and badminton $(n=97)$. The male community had done jogging $(\mathrm{n}=93)$ as a recreation activity that been done the most. The other two that been done by the male Klang community were activities at home which were surfing the internet $(\mathrm{n}=271)$ and playing a video game $(\mathrm{n}=85)$ and highlighted as the top five activities chosen by the male.

There were 187 female respondents out of the 421 respondents. The female community had done jogging $(\mathrm{n}=181)$ as a recreation activity that been done the most. Besides, the activities done by the female Klang community were activities at home which were surfing the internet $(n=287)$, cooking $(n=271)$, watching television $(n=164)$ and sleeping $(n=25)$. From this result, it shows that female in Klang community tends to do more on activities at home than sport or recreation activity.

Next, the finding refers to the activity done by a group of age. There were four groups of ages that have been classified by the researcher which were, adolescent, early adult, middle-aged adult, and late adult. There were 69 adolescents out of 421 total respondents. The adolescent of Klang community had done cinema $(n=48)$ as passive recreation activity that been done the most followed by jogging $(n=47)$. The other two activities that been done by adolescents of Klang community were activities at home which were badminton $(n=37)$ and basketball $(n=27)$. Lastly, watching television $(n=24)$ was the most activity at home that were highest done by adolescent and highlighted as the top five activities chosen by the adolescent.

Other than that, there were 241 early adults out of 421 total respondents. From overall early adult respondents, this group had done three activities at home as the highest activities which were surfing the internet $(n=355)$, cooking $(n=94)$, and watching television $(n=117)$. Besides, the other activity that been done the most were jogging $(n=144)$, as an active recreation activity and badminton $(n=94)$ as a sports activity. Furthermore, there were 78 middle-age adults out of 421 total respondents. From the overall of the middle-aged adult, they tend to do different types of activities which were cooking $(\mathrm{n}=105)$ as the activity at home. Next, the middle-aged adult had done badminton $(\mathrm{n}=98)$ as a sports activity. Other than that, this group has chosen an active recreation which was jogging $(n=94)$. On the other hand, there was the participation of passive recreation was hang out with family $(n=37)$ and cinema $(n=32)$.

Moreover, there were 33 late adults out of 421 total respondents. From the overall results of late adults, the most activities that been selected were five activities at home which were cooking $(n=113)$, watching television $(n=95)$, and surfing the internet $(n=40)$. Besides, walking at the park $(n=69)$, and jogging $(n=15)$ were the activities that been done by this group as it categorized as passive recreation activities and been highlighted to the most five activities done by a late adult group.

As the results are shown above, activities at home did dominate the activities done in a week by gender as surfing the internet $(\mathrm{n}=558)$ been frequently done and selected almost every day followed by jogging $(\mathrm{n}=274)$, cooking (271), futsal $(\mathrm{n}=109)$ and badminton $(\mathrm{n}=97)$. Besides, activities have also been done most based on the group of age which was surfing the internet $(n=395)$, followed by cooking $(n=343)$, 
jogging (300), watching television $(\mathrm{n}=236)$ and badminton $(\mathrm{n}=229)$. From these results, it did support a study in previous research, which was Aisyah (2018) stated that the improvement of technologies has contributed to the decrease of physical status in Malaysia. Other than that, this result did support a previous study from Hulteen (2017). According to Hulteen (2017), the activity that been done by gender usually had differences based on different regions globally.

\section{Public facilities existence in Klang community residents area}

Referring to the finding, there were 11 types of public facilities that might exist around the respondents and the easiness to access the public facilities. The types of public facilities that were on the list are football field, takraw court, basketball court, tennis court, volleyball court, badminton court, swimming pool, running track, sports complex, jogging track and recreational park and exercise. There were a total of 421 respondents answered all questions completely. Based on gender, there were 234 males respondents ant the others were female. As the male was higher than female, it shows that the most facility that exists around male respondents is a recreational park $(n=217)$ while the least public facilities around them are volleyball court $(\mathrm{n}=72)$. Then, based on the result, the highest frequency of the access that is too easy is a recreational park $(n=183)$. Besides, easy access to the public facility is the jogging track $(n=76)$. The difficult access is basketball court $(n=66)$ and the too difficult to access is the tennis court $(\mathrm{n}=117)$.

\section{Conclusion \& Recommendation}

As a conclusion, the overall result of the first objectives, the most activity done by a week by Klang community is the activity at home such as surfing the internet, cooking and watching tv. From this result, it shows that the statement from Aisyah (2018), stated that the decrease in physical activities is caused by the improvement of technology. While sports activities such as badminton and futsal still been run by Klang community, it still shows that the domination of technologies makes people do a less physical activity outside. Besides that, active and passive recreation activities such as jogging and gymnasium also had been picked but the development and improvement of technologies make these activities behind these activities that can be done at home.

Furthermore, there were public facilities that can be used by the Klang community. As from the results, overall of respondents based on highest chosen by gender stated that recreational park exists and too easy to access it. Hence, the existence of this facility can help Klang community to participate in physical activity but it needs to be practiced so that these facilities can be accessed by all of the Klang community. By this, the improvement of technologies will not dominate the activities of the Klang community.

Throughout this study, it is recommended that the researcher adding information and definition about terms. Next, the classification of the pattern needs to be stated more deeply as many kinds of activities that been run during free time fall into different categories based on a different study.

On the other hand, future research needs to adding more dimension so that the study will be more varied and at the same time, the research would be more strengthen as many dimensions been the study and more data can be collected.

\section{References}

Andrijašević, M., Paušić, J., Bavčević, T., \&Ciliga, D. (2005). Participation in leisure activities and self-perception of health in the students of the University of Split. Kinesiology, 37(1), 21-31.

AisyahWaheeda, R., Rheshara,.S., NikNasreen, N.K., Sabariah A.H. (2018). Physical Activity Status Of Community In Kg HuluChuchoh, Sungai Pelek, Sepang, Selangor, Malaysia. International Journal of Education and Research,1-10 
Amireault S. (2015). The use of Godin-Shephard Leisure-Time Physical Activity Questionnaire in Oncology Research: a systematic review.BMC Medical Research Methodology, 1- 14.

Ana-Maria Branea, Marius StelianGaman, StefanaBadescu. (2016). The importance of the public facilities network within the urban environment and its distribution within collective housing neighborhoods. Case study: Timisoara, Romania. Research Gate, 1-5.

Anna Ullenhag, L. K.-S. (2014). Differences in pattern of participation in Swedish children with and without disabilities.Disability and Rehabilitation, 464-471.

Brown M, Gordon WA. (1987) Impact of impairment on activity patterns of children. Arch Phys Med Rehabil 68: 828-832.

Chen, Y.-C., Li, R.-H., \& Chen, S.-H. (2013). Relationships among adolescents' leisure motivation,leisure involvement, and leisure satisfaction: A structural equation model. Social IndicatorsResearch, 110, 1187-1199. doi:10.1007/s11205-011-9979-2

City Population (2010).The population development of Klang as well as related information and services. Retrieved from Citypopulation.de

Cuypers, K., De Ridder, K., Kvaloy, K., Knudtsen, M. S., Krokstad, S., Holmen, J., \& Holmen, T. L. (2012). Leisure time activities in adolescence in the presence of susceptibility genes for obesity: risk or resilience against overweight in adulthood? The HUNT study. BMC Public Health, 12(1), 820.

Edginton, C. R., DeGraaf, D. G., Dieser, R. B., \&Edington, S. R. (2006). Leisure and life satisfaction foundation perspectives (4th ed.). New York, NY: McGraw-Hill.

Francis, N., \&Kentel, J. A. (2008). The fun factor: Adolescents' self-regulated leisure activity and the implications for practitioners and researchers. Leisure/Loisir, 32(1), 65-90.

Gary O'Donovan, I.-M.L. (2017). Association of "Weekend Warrior" and Other Leisure Time Physical Activity Patterns With Risks for All-Cause, Cardiovascular Disease, and Cancer Mortality. JAMAInternalMedicine, 335-342.

Geidne, S., Fredriksson, I., \& Eriksson, C. (2016). What motives are important for participation in leisure-time activities at Swedish youth centers? Health Education Journal, 75(8), 972-985.

Godbey, G. (1994). Leisure in your life: An exploration. State College, PA: Venture Publishing, Inc.

Helsen Werner F. (1998). Team Sports and the theory of Deliberate Practice. Journal of Sport \& Exercise Psychology, 12-34

Henderson, K. A. (1990). The meaning of leisure for women: An integrative review of the research. Journal of Leisure Research, 22(2), 228-243

Hulteen R.M, (2016). Global Participation in sport and leisure-time physical activities: A systematic review and meta-analysis. Global sport and leisure-time physical activity, 1-35.

Iso-Ahola, S. E. (1983). Towards a social psychology of recreational travel. Leisure Studies, 2(1), 4556.

Jong-Ho Kim, S. L. (2018).Types of leisure, leisure motivation, and well-being. World Leisure Journal, 1-15.

Josephine Chau, T. C.-Y. (2017). Trends in prevalence of leisure time physical activity and inactivity: results from Australian National Health Surveys 1989 to 2011. Sport and physical activity, 617624.

Joudrey, A. D., \& Wallace, J. E. (2009). Leisure as a coping resource: A test of the job demandcontrol-support model. Human Relations, 62(2), 195-217.

King, G., Petrenchik, T., Law, M., \& Hurley, P. (2009). The enjoyment of formal and informal recreation and leisure activities: A comparison of school-aged children with and without physical disabilities. International Journal of Disability, Development and Education, 56(2), 109-130.

Leversen, I., Danielsen, A. G., Birkeland, M. S., \&Samdal, O. (2012).Basic psychological need satisfaction in leisure activities and adolescents' life satisfaction. Journal of Youth and Adolescence, 41(12), 1588-1599.

Mannell, R. C., \&Kleiber, D. A. (1997). A social psychology of leisure. Venture Publishing Inc..

Neira, C. J. B., \& Barber, B. L. (2012).Exploring the positive peer and identity experiences occurring in Australian adolescents' leisure activities. The Educational and Developmental Psychologist, 29(1), 44-51.

Newacheck PW, Halfon N. (1998) Prevalence and impact of disabling chronic conditions in childhood. Am J Public Health 88: 610-617. 
DOI: https://doi.org/10.47405/mjssh.v5i2.355

P. Aruna (2017). BMI Research: Malaysians expected to spend more on leisure and entertainment. Retrieved from The Star newspaper.

Passmore, A., \& French, D. (2001).Development and administration of a measure to assess adolescents' participation in leisure activities. Adolescence, 36(141), 67-67.

PetrBadura, A. M. (2015). When children play, they feel better: organized activity participation and health in adolescents. BMC Public Health, 1-8.

Petry NM. Gerontologist (2002).A comparison of young, middle-aged, and older-adult treatmentseeking pathological gamblers. PubMed, 92-99.

Stephanie Paillard-Borg, H.-X.W. (2009). Pattern of participation in leisure activities among older people in relation to their health conditions and contextual factors: a survey in a Swedish urban area. Cambridge Journal, 803 - 821.

Torkildsen, G. (2005). Leisure and Recreation Management, Great Britain.

Willits, D. S. (2017). Adolescent and Adult Pattern: A Reassessment. Journal of Leisure Research, 319-330. 